\begin{tabular}{|c|c|}
\hline \multirow{3}{*}{ 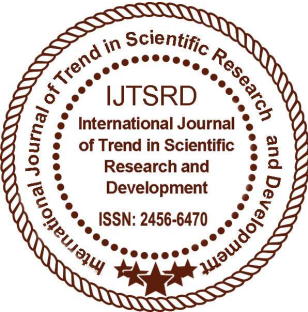 } & $\begin{array}{l}\text { International Journal of Trend in Scientific } \\
\text { Research and Development (IJTSRD) }\end{array}$ \\
\hline & International Open Access Journal \\
\hline & ISSN No: 2456 - 6470 | www.ijtsrd.com | Volume - 1 | Issue - 6 \\
\hline
\end{tabular}

\title{
Studies the physico-chemical parameters of water, soil and the nutritional values of edible cephalopods found at Digha coast, West Bengal, India
}

\author{
Das Manotosh \\ Research Scholar, Department of Aquaculture \\ Management \& Technology, Vidyasagar University, \\ Midnapore, West Bengal, India.
}

Fishery Field Assistant, Department of Fishery, Government of West Bengal

\author{
Maity Joydev \\ Assistant Professor, Department of Aquaculture \\ Management \& Technology, Vidyasagar University, \\ Midnapore, West Bengal, India
}

\section{ABSTRACT}

India is a high speed population growing country and present population of India is about 127 crores. Among them a huge number of our children have been suffering from mal-nutritional diseases. They need protein feed and molluscs meat especially cephalopods meat is a good source of protein. India harvested 1.73 lakh tones of cephalopods, 0.04 lakh tones of bivalves and 0.02 tones of gastropods from Indian marine resources like Arabian sea, Bay of Bengal and Indian Ocean in the year 2013-2014. The people of southern states of India consume molluscs meat in huge quantity as their everyday protein resource food. The local poor people at Digha eat occasionally only cephalopods meat. From our study for about last 5 years (August - 2012 to July - 2017) we get 12 bivalves species belonging to 5 orders, 6 families and 8 genera out of 54 available bivalves species, 2 gastropods species belonging to 2 orders, 2 families and 2 genera out of 35 available gastropods species and 4 cephalopods species belonging to 3 orders, 3 families and 4 genera out of 4 available cephalopods species are edible. This study is conducted to make awareness among the people at Digha especially poor coastal villagers and fisher folk communities about nutritive values of molluscs meat and its beneficial effect on human body.
Keywords: Bio-diversity, Cephalopods, Digha Coast, Ecosystem, Molluscs, Nutritional Values

\section{INTRODUCTION}

The word 'Mollusca' is a Latin word which means 'soft'. Aristotle is the father of the word 'Mollusca'. Molluscs are benthic organisms that live on or in, the bottom of the water body with greater than $1.0 \mathrm{~mm}$ in size. Its body is made up of head, visceral mass and locomotory or digging foot, epidermis is forming mantle, secrets calcareous spicules or produces one or more shells. Chitinous is ribbon like or radial having small teeth in the mouth but absent in bivalves. They are soft bodied animals, a large and most important group of invertebrates which occupies all the possible habitats except aerial. Molluscs are the largest phylum among the marine invertebrates and it occupies $23 \%$ of total marine animals. Linnaeus (1758) adopted the name, Mollusca, a term which was in fact proposed by Johnston (1650), but without developing any real concept of the phylum. Cuvier (1795) had shown better understanding of the group, and his concept approximates to modern ideas. In the beginning several other groups such as barnacles, brachiopods and other shelled forms were classified together with the molluscs. They are found 10190 meter deep in the 
ocean to 5000 meter of elevation. It is a highly diversified group, differs in size, shape, number as well as its habit and habitat. Winckworth (1940), estimates 31643 number of marine molluscs, 8765 number of freshwater molluscs and 24503 number of terrestrial molluscs, making a total number of 64,911 molluscan species (approx. 65,000) ${ }^{1}$.

Subba Rao (1998) made a conservative estimate 66535 number of molluscan species of which the Indian share is 5070 number of molluscan species, among them 3400 marine molluscs, 183 fresh water molluscs and 1487 terrestrial molluscs ${ }^{2}$.

Chapman (2009). estimates of accepted described living species of molluses vary from 50,000 to a maximum of 120,000 species. In 1969 David Nicol estimated the probable total numbers of living molluscs at 107,000 of which were about 12,000 fresh-water gastropods and 35,000 terrestrial. The Bivalvia would comprise about $14 \%$ of the total and the other five classes less than $2 \%$ of the living molluscs. Haszprunar in 2001 estimated about 93,000 named species which include $23 \%$ of all named marine organisms. Molluscs are second only to arthropods in numbers of living animal species far behind the arthropods 1,113,000 but well ahead of chordates' 52,000. About 200,000 living species in total are estimated and 70,000 fossil species, although the total number of molluscs species ever to have existed, whether or not preserved, must be many times greater than the number alive today ${ }^{3-4}$.

The marine molluscs have an important place in an ecosystem. They are the major food source for human as well as other secondary consumers in the ecosystems which are also important bio-resource like fishes. Molluscs play a major role in ecosystem by filtering phytoplankton and then acting as a good source of food for higher organisms living in upper tropic level such as fishes. They oxygenate the bottom by reworking sediments and play a basic role in breaking down organic materials before bacterial remineralization. A number of molluscs particularly cephalopods are consumed by human and others. They are also used as biological indicators because they can provide information on environmental conditions either due to the sensitivity of single species (indicator species) or because of some general feature that makes them integrate environmental signals for a long period of time. ${ }^{5-6}$
Diversity is also evident in mollusca in their feeding habits. They are herbivores, carnivores, scavengers and deposit feeders, suspension feeders. Sometime they are considered as parasites and show commensalism $^{5-6}$.

Some studies on marine biodiversity at Digha coast as well as surrounding coastal areas were carried out in the past (Subba Rao, et al., 1996). These studies started with work by Goswami (1992) which provides the overview of marine biodiversity at Digha coast for the fast time. But, the first comprehensive account of marine molluscs was prepared by Ramkrishna et al., 2003. Keeping view of these studies, the study was planned to monitor the population of individual group, their distribution and status. This deals with comparative account of marine molluscan fauna at various study locations $^{6-7}$.

Both shell and meat of molluscs are used in several items. Immensely great is the utilization of molluscs shell lime in all masonry construction and for white washing the buildings. Their use as fertilizers in plantations has also gained momentum in the recent years. From sandy shores washed shell are gathered in quantities. After the removal of meats for food, hells of all edible forms are collected. Dead shells in considerable quantities are annually gathered from oyster and clam beds, shells of even pearl oysters and window - pan oysters are much used for lime. All molluscan shells, big or small, dull ones or beautifully tined ones go into the making of toys, boxes, lamp bases of shades, garlands, rings, ash-trays, knife handles etc. Most of the polished shells are sold as cunios, cameos (a gem with figure carved in relief) are carved on large shells by removal of the surface layers and exposing the deeper layers of varied colour pattern. The corridors of the temples are flooded with soaps selling such articles. Almost obsolete now are much used as the whelks for purple dye, cuttle bone for polishing furniture, sepia for drawing ink, Molluscan shells are pulverized and used in poultry feed for the birds to lay eggs with thick and perfect shells. The available marine molluscan shells are used for home decoration. Paphia textile is used in garment industry due to presence of dye and Donax incarnates is used as anticoagulant because it contains heparin in its body. The chank shell (Sankha) is used to produce sound to make people aware at the time of Earthquake and also other natural/manmade calamities. The chank shell producing sound is used to kill disease causing organisms. Most molluscan shells are used for 
multifarious purposes but the chank shell surpasses them all for it has played a significant role in the observation of traditional customs of our religious faiths of the Indians in general and the Hindu communities in particular who regard it is a divine symbol of all success, peace and prosperity in life and it is therefore decided for worship especially the sinistral chank which is worth its weight in gold.

It is studied on marine molluscan fauna found at Digha coast and among them which are edible species, their nutritive value and consumption status among the local people. The cephalopods meat is utilized by local common people as their food. There is some shell fish processing industry at Digha and adjacent area like Talsary of Odisha where the shell without meat is dried unhygienically in sun shine and crushed in machine for preparation of shell dust which is used for preparation of lime and feed of poultry birds. Shell meat is quitely neglected there but the meat of edible molluscs can be used as delicious and nutritious food of human beings and meat of all molluscs can be used as feed of ducks, carnivorous fishes, prawns, shrimps etc. We make aware all the owners and workers of shell fish industries about the various utilizations of molluscs shell and meat. Pollution is a major problem in shell fish processing industries at Digha. Bad odour forms there during decomposition of meat. It is needed to take some measure and to make the place pollution free.

\section{MATERIALS AND METHODS:}

The history of old and new Digha both is not so old. In 18th century, the Digha village under Birkul Parganas under the British rules was a health resort for the British in India. It was considered as a most popular weekend beach resort in our then the Bengal. In the present day, about 40 lakhs or more tourists visit Digha every year. There are about 200 or more lodges built up for tourists night stay. Hotel business is a most popular business at Digha and a major percentage of local people take it as their occupation. Digha beach is situated close to the Gangetic mouth on the east coast of India facing the Bay of Bengal at latitude $21^{\circ} 36^{\prime} 30^{\prime \prime} \mathrm{N}$ and longitude $87^{\circ} 30^{\prime} \mathrm{E}$. It is under Purba Medinipur district. There is a concrete road from Sea hawk ghat to Paschim gadadharpur. The sea beach is one side of the road and on the other side, there is forest of casuarinas and Keya trees.

There are so many varieties of molluscan species inhabit at Digha and its surrounding coastal areas. The coastal line is straight \& large inter-tidal zone. The beach is flat $\&$ compact. The beach is made up of sand mixed with variable proportions of silt \& which makes it very compact. Digha has potential coastal line of about $10 \mathrm{~km}$, which offers scope for more effective exploitation of marine fishery resources. There are 8 number of different ghats (spots) studies at Digha coast.

\section{RESULTS AND DISCUSSIONS:}

\section{A. Physicochemical Parameters of Water and Soil at Digha Coast:}

The physicochemical parameters of water and soil at Digha sea beach (selected three spots like Digha mohana, New Digha and Udaypur) are studied at the time of high tide level, mean tide level and low tide level during pre monsoon (from the month of March to May), monsoon (from the month of June to August) and post monsoon period (from the month of September to February).

We collect water and soil sample from the monsoon period, 2013 to pre monsoon period, 2015. We test the physicochemical parameters of water and soil in laboratory. According to the study it is seen that the water temperature is highest $(32.560 \mathrm{C})$ during pre monsoon period, 2015 at Udaypur ghat and lowest temperature (13.490C) is recorded during post monsoon period, 2013 - 14 at Udaypur ghat. The temperature fluctuation is $19.070 \mathrm{C}$ during 2 years study period. Water temperature in details is seen in table - 1 
International Journal of Trend in Scientific Research and Development (IJTSRD) ISSN: 2456-6470

\begin{tabular}{|l|l|l|l|l|l|l|l|l|l|}
\multirow{2}{*}{\multicolumn{1}{c|}{ Season }} & \multicolumn{3}{c}{ A-1 } & \multicolumn{3}{c|}{ A-II } & \multicolumn{3}{c|}{ A-III } \\
\cline { 2 - 10 } & HTL & MTL & LTL & HTL & MTL & LTL & HTL & MTL & LTL \\
\hline MON, 13 & 30.75 & 31.51 & 31.21 & 30.51 & 29.83 & 29.23 & 30.32 & 30.21 & 30.74 \\
\hline POM, 13-14 & 15.31 & 15.22 & 15.25 & 14.25 & 14.95 & 14.76 & 13.49 & 13.86 & 14.48 \\
\hline PRM, 14 & 30.54 & 30.79 & 31.10 & 30.25 & 29.46 & 29.50 & 31.21 & 31.31 & 31.36 \\
\hline MON, 14 & 30.31 & 30.24 & 30.21 & 29.42 & 30.16 & 30.08 & 30.80 & 30.83 & 30.95 \\
\hline POM, 14-15 & 15.55 & 15.34 & 15.58 & 15.31 & 20.52 & 14.56 & 14.26 & 14.38 & 14.53 \\
\hline PRM, 15 & 31.61 & 31.72 & 31.83 & 31.45 & 30.96 & 31.39 & 32.42 & 31.96 & 32.56 \\
\hline
\end{tabular}

Table - 1: Seasonal (Mean) variations of Temperature $\left({ }^{\circ} \mathrm{C}\right)$ of Interstitial Water collected from Digha Mohana, New Digha and Udaypur at A-I, A-II and A-III respectively during June, 2013 to May, 2015

In case of water $\mathrm{pH}$, it is highest (8.62) during pre monsoon period, 2015 at Udaypur ghat and lowest (7.01) during monsoon period, 2014 at Digha mohana. $\mathrm{pH}$ fluctuation is 1.61 and it is little. Water $\mathrm{pH}$ in details is seen in table -2

\begin{tabular}{|l|l|l|l|l|l|l|l|l|l|}
\hline \multirow{2}{*}{ Season } & \multicolumn{3}{c|}{ A-1 } & \multicolumn{3}{c|}{ A-II } & \multicolumn{3}{c|}{ A-III } \\
\cline { 2 - 11 } & HTL & MTL & LTL & HTL & MTL & LTL & HTL & MTL & LTL \\
\hline MON, 13 & 7.42 & 7.48 & 7.56 & 7.39 & 7.51 & 7.29 & 7.31 & 7.35 & 7.48 \\
\hline POM, 13-14 & 7.75 & 7.77 & 7.81 & 7.59 & 7.82 & 7.69 & 7.61 & 7.56 & 7.49 \\
\hline PRM, 14 & 8.21 & 8.21 & 7.91 & 7.89 & 7.98 & 8.06 & 7.78 & 7.97 & 7.99 \\
\hline MON, 14 & 7.19 & 7.01 & 7.11 & 7.14 & 7.32 & 7.28 & 7.35 & 7.43 & 7.51 \\
\hline POM, 14-15 & 7.72 & 7.59 & 7.50 & 7.58 & 7.59 & 7.81 & 7.54 & 7.56 & 7.58 \\
\hline PRM, 15 & 7.21 & 7.98 & 8.23 & 8.02 & 8.12 & 8.16 & 8.16 & 8.39 & 8.62 \\
\hline
\end{tabular}

Table - 2: Seasonal (Mean) variations of pH of Interstitial Water collected from Digha Mohana, New Digha and Udaypur at A-I, A-II and A-III respectively during June, 2013 to May, 2015

We also recorded the mean value of Dissolved Oxygen (DO) in water. The highest DO level is $5.41 \mathrm{ppm}$ during monsoon, 2014 at Udaypur ghat and lowest level is $3.32 \mathrm{ppm}$ during pre monsoon, 2015 at Digha mohana and Udaypur ghat also. Dissolved $\mathrm{O}_{2}$ level fluctuates $2.09 \mathrm{ppm}$ in 2 years study period. Overall DO level is high throughout the year due to high speed airflow and tidal amplitude. DO level in water is seen in table -3

\begin{tabular}{|l|l|l|l|l|l|l|l|l|l|}
\hline \multicolumn{1}{|c}{ Season } & \multicolumn{3}{c}{ A-1 } & \multicolumn{3}{c|}{ A-II } & \multicolumn{3}{c|}{ A-III } \\
& HTL & MTL & LTL & HTL & MTL & LTL & HTL & MTL & LTL \\
\hline MON, 13 & 4.83 & 4.81 & 3.75 & 5.48 & 5.04 & 4.59 & 5.40 & 4.29 & 3.72 \\
\hline POM, 13-14 & 4.37 & 3.79 & 3.36 & 4.29 & 3.92 & 3.82 & 5.01 & 4.21 & 4.00 \\
\hline PRM, 14 & 4.21 & 3.74 & 3.52 & 4.29 & 3.97 & 3.56 & 4.99 & 4.61 & 3.57 \\
\hline MON, 14 & 4.98 & 4.44 & 3.82 & 4.65 & 4.92 & 4.69 & 5.41 & 4.79 & 4.02 \\
\hline POM, 14-15 & 4.52 & 3.87 & 3.32 & 4.25 & 4.15 & 4.02 & 4.98 & 4.48 & 3.69 \\
\hline PRM, 15 & 4.02 & 3.85 & 3.32 & 4.27 & 4.15 & 3.59 & 4.36 & 3.58 & 3.32 \\
\hline
\end{tabular}

Table - 3: Seasonal (Mean) variations of Dissolved Oxygen (mg/l) of Interstitial Water collected from Digha mohana, New Digha and Udaypur at A-I,A-II and A-III respectively during June, 2013 to May, 2015

The highest salinity of water $(25.29 \mathrm{ppm})$ is recorded during pre monsoon period, 2015 at Digha mohana and lowest (7.77 ppm) during monsoon, 2014 at Udaypur ghat. Water salinity fluctuates $17.52 \mathrm{ppm}$. This high fluctuation is occurred due to high temperature in summer hours and addition of fresh water from a canal (Dubda water basin) and direct rainfall on sea water. Water salinity is seen in table -4 
International Journal of Trend in Scientific Research and Development (IJTSRD) ISSN: 2456-6470

\begin{tabular}{|l|l|l|l|l|l|l|l|l|l|}
\multirow{2}{*}{\multicolumn{1}{c|}{ Season }} & \multicolumn{3}{c|}{ A-1 } & \multicolumn{3}{c|}{ A-II } & \multicolumn{3}{c|}{ A-III } \\
\cline { 2 - 12 } & HTL & MTL & LTL & HTL & MTL & LTL & HTL & MTL & LTL \\
\hline MON, 13 & 10.97 & 11.42 & 11.53 & 9.87 & 10.10 & 10.74 & 8.26 & 8.63 & 9.31 \\
\hline POM, 13-14 & 16.65 & 17.14 & 17.35 & 14.91 & 15.31 & 15.87 & 12.99 & 13.49 & 13.65 \\
\hline PRM, 14 & 25.01 & 24.68 & 24.45 & 22.70 & 22.67 & 22.32 & 20.80 & 20.31 & 20.19 \\
\hline MON, 14 & 10.02 & 10.46 & 10.87 & 9.55 & 9.98 & 10.06 & 7.77 & 8.16 & 8.43 \\
\hline POM, 14-15 & 16.78 & 16.98 & 17.17 & 15.19 & 15.49 & 15.61 & 13.92 & 14.19 & 14.40 \\
\hline PRM, 15 & 24.81 & 25.08 & 25.29 & 24.05 & 24.37 & 24.55 & 22.32 & 22.52 & 22.47 \\
\hline
\end{tabular}

Table - 4: Seasonal (Mean) variations of Salinity (ppm) of Interstitial Water collected from Digha mohana, New Digha and Udaypur at A-I, A-II and A-III respectively during June, 2013 to May, 2015

The mean value of water turbidity is highest (361.1 NTU) during monsoon, 2013 at Digha mohana due to flow of water of the canal (Dubda water basin) and lowest (231 NTU) during post monsoon period, 2014-15 at Udaypur ghat. The water turbidity fluctuates 131.1 NTU, recorded during 2 years range study period.

Turbidity in details is seen in table -5

\begin{tabular}{|l|l|l|l|l|l|l|l|l|l|}
\hline \multicolumn{1}{c}{ Season } & \multicolumn{3}{c|}{ A-1 } & \multicolumn{3}{c|}{ A-II } & \multicolumn{3}{c|}{ A-III } \\
\cline { 2 - 10 } & HTL & MTL & LTL & HTL & MTL & LTL & HTL & MTL & LTL \\
\hline MON, 13 & 296 & 286 & 356 & 301 & 316.6 & 324 & 287.6 & 272.5 & 272.5 \\
\hline POM, 13-14 & 326 & 318 & 336 & 238.6 & 279 & 275 & 300 & 282 & 268.1 \\
\hline PRM, 14 & 326.9 & 326.3 & 363.1 & 284.6 & 321 & 320 & 320 & 298 & 278 \\
\hline MON, 14 & 283.1 & 298.5 & 316 & 283.5 & 326 & 322.0 & 298.3 & 282.1 & 276 \\
\hline POM, 14-15 & 306.9 & 316 & 312 & 276.5 & 291 & 293.2 & 276 & 263.1 & 231 \\
\hline PRM, 15 & 243.4 & 248.1 & 248.2 & 251 & 301 & 298.1 & 273.2 & 266 & 268.1 \\
\hline
\end{tabular}

Table - 5: Seasonal (Mean) variations of Turbidity (NTU) of Interstitial Water collected from Digha mohana, New Digha and Udaypur at A-I, A-II and A-III respectively during June, 2013 to May, 2015

In case of Soil, the highest temperature $\left(34.12^{\circ} \mathrm{C}\right)$ is recorded during pre monsoon period, 2014 at new Digha ghat and lowest temperature is $15.36^{\circ} \mathrm{C}$ during post monsoon period, $2014-15$ at Udaypur ghat. Temperature fluctuation is $18.76^{\circ} \mathrm{C}$. This is because very hot weather in summer season and cool weather in winter season. Soil temperature in details is seen in table -6

\begin{tabular}{|l|l|l|l|l|l|l|l|l|l|}
\hline \multicolumn{1}{|c|}{ Season } & \multicolumn{3}{c|}{ A-1 } & \multicolumn{3}{c|}{ A-II } & \multicolumn{3}{c|}{ A-III } \\
\cline { 2 - 12 } & HTL & MTL & LTL & HTL & MTL & LTL & HTL & MTL & LTL \\
\hline MON, 13 & 31.42 & 31.84 & 31.98 & 31.45 & 31.89 & 31.85 & 31.22 & 31.45 & 31.26 \\
\hline POM, 13-14 & 15.58 & 16.26 & 16.16 & 15.61 & 15.68 & 15.52 & 16.28 & 16.05 & 16.04 \\
\hline PRM, 14 & 34.00 & 33.85 & 33.46 & 34.12 & 34.03 & 34.00 & 33.22 & 32.98 & 33.21 \\
\hline MON, 14 & 31.21 & 30.74 & 31.10 & 31.13 & 30.35 & 31.21 & 30.54 & 30.54 & 30.78 \\
\hline POM, 14-15 & 15.66 & 15.56 & 15.68 & 15.41 & 15.32 & 15.36 & 15.86 & 15.84 & 15.78 \\
\hline PRM, 15 & 32.98 & 33.00 & 33.01 & 32.58 & 32.55 & 32.50 & 33.01 & 32.89 & 32.99 \\
\hline
\end{tabular}

Table - 6: Seasonal (Mean) variations of Temperature $\left({ }^{\circ} \mathrm{C}\right)$ of Soil collected from Digha Mohana, New Digha and Udaypur at A-I, A-II and A-III respectively during June, 2013 to May, 2015

We study the $\mathrm{pH}$ value of soil, taking soil sample from three specific ghats. The highest $\mathrm{pH}$ is recorded 9.29 during pre monsoon period, 2014 at Digha mohana and lowest $\mathrm{pH}$ value is 7.68 during monsoon period, 2014 at Digha mohana and new Digha ghat. Soil pH fluctuation is 1.61. Soil pH in details is seen in table - 7 
International Journal of Trend in Scientific Research and Development (IJTSRD) ISSN: 2456-6470

\begin{tabular}{|l|l|l|l|l|l|l|l|l|l|}
\multirow{2}{*}{\multicolumn{1}{c|}{ Season }} & \multicolumn{3}{c|}{ A-1 } & \multicolumn{3}{c|}{ A-II } & \multicolumn{3}{c|}{ A-III } \\
\cline { 2 - 12 } & HTL & MTL & LTL & HTL & MTL & LTL & HTL & MTL & LTL \\
\hline MON, 13 & 7.88 & 8.74 & 8.26 & 8.26 & 8.06 & 7.89 & 8.56 & 8.79 & 8.58 \\
\hline POM, 13-14 & 8.26 & 8.23 & 8.26 & 8.26 & 8.26 & 8.07 & 8.45 & 8.41 & 9.23 \\
\hline PRM, 14 & 9.29 & 8.52 & 8.08 & 8.54 & 8.42 & 8.23 & 8.92 & 8.35 & 8.54 \\
\hline MON, 14 & 7.68 & 8.08 & 8.05 & 7.68 & 8.50 & 8.25 & 8.82 & 8.23 & 8.56 \\
\hline POM, 14-15 & 8.35 & 8.60 & 8.17 & 8.40 & 8.49 & 7.98 & 7.90 & 7.70 & 8.43 \\
\hline PRM, 15 & 8.60 & 8.40 & 8.56 & 8.60 & 8.26 & 8.03 & 8.23 & 8.35 & 8.35 \\
\hline
\end{tabular}

\section{Table - 7: Seasonal (Mean) variations of pH of Soil collected from Digha Mohana, New Digha and Udaypur at A-I, A-II and A-III respectively during June, 2013 to May, 2015}

The salinity of soil is highest (32.65 ppm) during pre monsoon period, 2015 at new Digha ghat and lowest $(11.20 \mathrm{ppm})$ during monsoon period, 2013 at new Digha ghat. Soil salinity fluctuation ranges 21.45 ppm due to temperature difference. Soil salinity in details is seen in table - 8

\begin{tabular}{|l|l|l|l|l|l|l|l|l|l|}
\multirow{2}{*}{\multicolumn{1}{c|}{ Season }} & \multicolumn{4}{c|}{ A-1 } & \multicolumn{3}{c|}{ A-II } & \multicolumn{3}{c|}{ A-III } \\
\cline { 2 - 11 } & HTL & MTL & LTL & HTL & MTL & LTL & HTL & MTL & LTL \\
\hline MON, 13 & 11.20 & 11.42 & 11.44 & 13.50 & 13.35 & 15.34 & 12.32 & 12.42 & 13.43 \\
\hline POM, 13-14 & 21.42 & 19.87 & 20.65 & 22.52 & 22.96 & 22.34 & 22.62 & 22.72 & 22.39 \\
\hline PRM, 14 & 25.82 & 25.98 & 25.88 & 27.53 & 27.85 & 26.99 & 27.50 & 27.76 & 27.24 \\
\hline MON, 14 & 17.75 & 12.35 & 12.98 & 13.59 & 13.83 & 13.86 & 12.56 & 13.10 & 12.68 \\
\hline POM, 14-15 & 21.46 & 22.22 & 21.09 & 22.89 & 22.78 & 23.29 & 22.69 & 21.46 & 22.42 \\
\hline PRM, 15 & 30.09 & 30.58 & 30.65 & 30.46 & 31.19 & 32.65 & 30.26 & 30.60 & 30.86 \\
\hline
\end{tabular}

Table - 8: Seasonal (Mean) variations of Salinity (ppm) of Soil collected from Digha Mohana, New Digha and Udaypur at A-I, A-II and A-III respectively during June, 2013 to May, 2015

\section{B). Edible Molluscan Species:}

During the study period from August - 2012 to July - 2017 we had an interview with some local poor villagers and fishermen lived in coastal villages at Digha. From this survey it is known that 12 bivalves species belonging to 5 orders, 6 families and 8 genera out of 54 available bivalves species, 2 gastropods species belonging to 2 orders, 2 families and 2 genera out of 35 available gastropods species and 4 cephalopods species belonging to 3 orders, 3 families and 4 genera out of 4 available cephalopods species are edible. But it is a matter of concern that most of the local people do not know that few molluscan species is edible, the meat is highly nutritious and few are delicious. They do not consume it. A very little number of coastal villagers consume the meat of cephalopods sometimes. They use marine fishes as their daily non vegetarian food item because marine fishes are abundantly available and cheap. But it is true that the edible molluscan meat is cheaper than any kind of marine fishes available at Digha coast. 
International Journal of Trend in Scientific Research and Development (IJTSRD) ISSN: 2456-6470

\begin{tabular}{|c|c|c|c|}
\hline Sl.No. & Family Name (6) & Genera (8) & Specimen (12) \\
\hline \multirow[t]{3}{*}{1.} & \multirow{3}{*}{ Arcidae } & \multirow[t]{3}{*}{ Anadara } & Anadara granosa (Linnaeus, 1758) \\
\hline & & & Anadara inequivalvis (Bruquiere, 1789) \\
\hline & & & Anadara antiquata (Linnaeus, 1758) \\
\hline \multirow[t]{2}{*}{2.} & \multirow[t]{2}{*}{ Donacidae } & \multirow[t]{2}{*}{ Donax } & Donax incarnates (Gmelin, 1791) \\
\hline & & & Donax scortum (Linnaeus, 1758) \\
\hline 3. & Mytilidae & Perna & Perna viridis (Linnaeus, 1758) \\
\hline \multirow[b]{2}{*}{4.} & \multirow[t]{2}{*}{ Ostreidae } & Saccostrea & Saccostrea cucullata (Born, 1778) \\
\hline & & Crassostrea & Crassostrea gryphoides (Scholthein, 1813) \\
\hline 5. & Solenidae & Solen & Solen brevis (Gray, 1842) \\
\hline \multirow[t]{3}{*}{6.} & \multirow[t]{3}{*}{ Veneridae } & Katelysia & Katelysia opima (Gmelin, 1791) \\
\hline & & \multirow[t]{2}{*}{ Meretrix } & Meretrix meretrix (Linnaeus, 1758) \\
\hline & & & Meretrix casta (Gmelin, 1791) \\
\hline
\end{tabular}

Table - 9: Edible marine bivalvia available at Digha coast ${ }^{8}$.

\begin{tabular}{|l|l|l|l|}
\hline \multicolumn{1}{|c|}{$\begin{array}{c}\text { SI. } \\
\text { No. }\end{array}$} & \multicolumn{1}{|c|}{ Family Name } & \multicolumn{1}{|c|}{ Genera (2) } & \multicolumn{1}{|c|}{ Specimen (2) } \\
\hline 1. & Olividae & Olivancillaria & Olivancillaria gibbosa (Born, 1778) \\
\hline 2. & Trochidae & Umbonium & Umbonium vestiarium (Linnaeus, 1758) \\
\hline
\end{tabular}

Table - 10: Edible marine gastropoda available at Digha coast ${ }^{8}$.

\begin{tabular}{|l|l|l|l|}
\hline $\begin{array}{l}\text { Sl. } \\
\text { No. }\end{array}$ & \multicolumn{1}{|c|}{ Family Name } & \multicolumn{1}{|c|}{$\begin{array}{c}\text { Genera } \\
(\mathbf{3})\end{array}$} & \multicolumn{1}{|c|}{ Specimen (4) } \\
\hline 1. & Loliginidae & Loligo & Loligo duvauceli (d'Orbigny, 1848) \\
\hline 2. & Octopodidae & Octopus & Octopus macropus (Risso, 1826) \\
\hline 3. & Sepiidae & Sepia & Sepia aculeata (Ferussac and d'Orbigny, 1848) \\
\cline { 3 - 4 } & & Sepiella & Sepiella inermis (Ferussac and d'Orbigny, 1848) \\
\hline
\end{tabular}

Table - 11: Edible marine cephalopoda available at Digha coast ${ }^{8}$ 


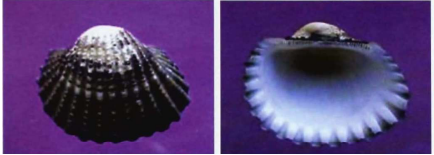

Fig - 1, Anadara granosa

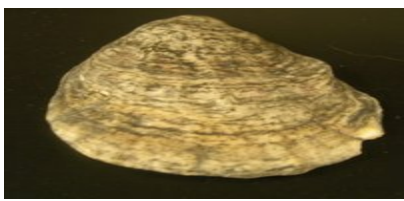

Fig - 4, Crassostrea gryphoides

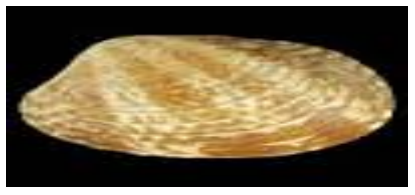

Fig - 7, Katelysia opima

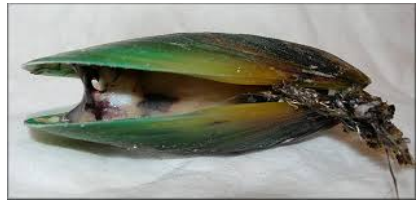

Fig - 10, Perna viridis

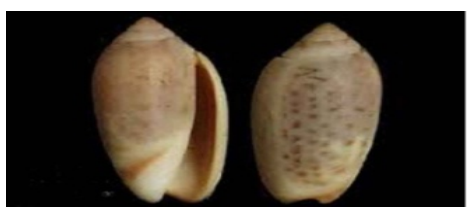

Fig - 13, Olivancillaria gibbosa

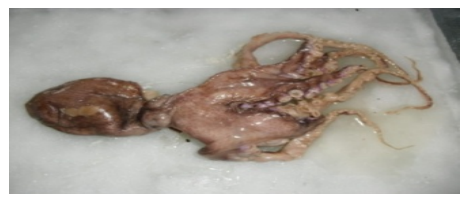

Fig - 16, Octopus macropus

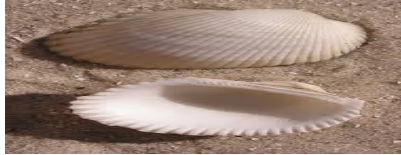

Fig - 2, Anadara inequivalvis

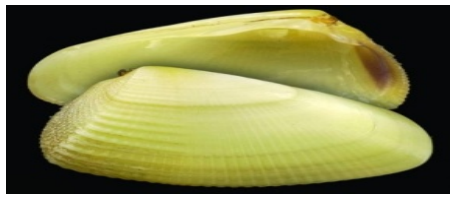

Fig - 5, Donax incarnates

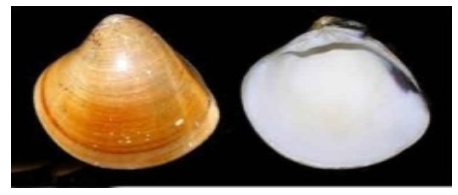

Fig - 8, Meretrix meretrix

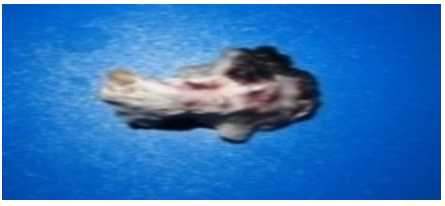

Fig - 11, Saccostrea cucullata

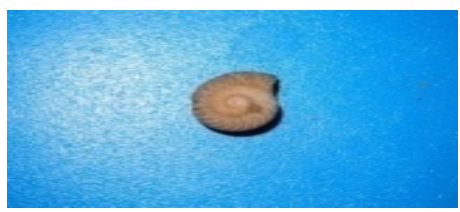

Fig - 14, Umbonium vestiarium

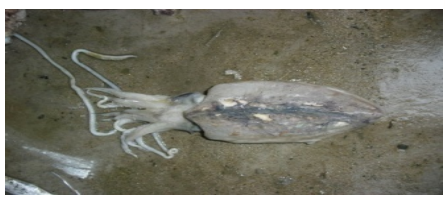

Fig -17, Sepia aculeata

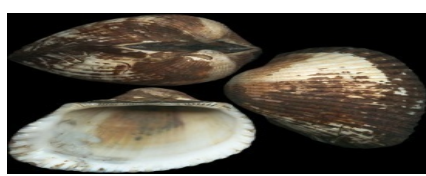

Fig - 3, Anadara antiquata

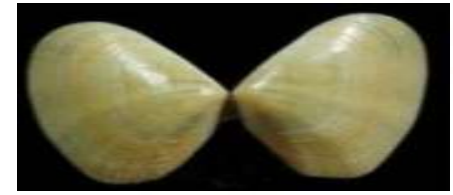

Fig - 6, Donax scortum

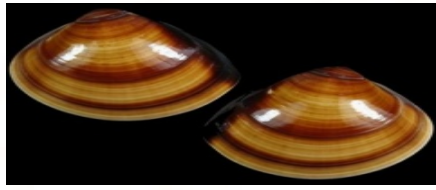

Fig-9, Meretrix casta

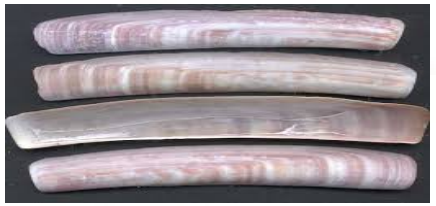

Fig - 12, Solen brevis

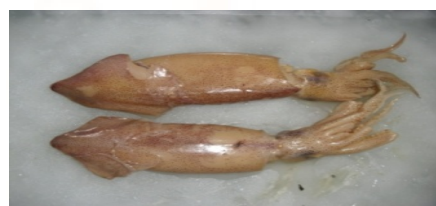

Fig - 15, Loligo duvauceli

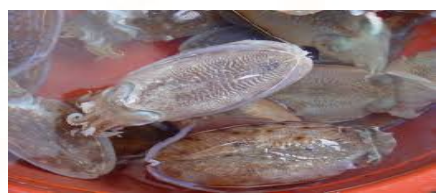

Fig - 18, Sepiella inermis

\section{Nutritional Values of Available Edible Cephalopods:}

The Moisture content of overall edible marine molluscs is relatively high throughout the year. During monsoon season, high values of moisture content are obtained from the month July and onwards. Low values of moisture content are decreased from November and onwards during the post monsoon season. The average value of moisture content is low during the pre monsoon period compared to the monsoon and post monsoon seasons. Lowest and highest values of moisture content are observed in March and July in a year respectively. In general, the moisture content of the tissue of bivalves usually gives an indication of the time of spawning ${ }^{\mathbf{9 - 1 3}}$. The result after analysis of moisture content in wet condition of 4 edible cephalopods is shown in table number $-12$ 
International Journal of Trend in Scientific Research and Development (IJTSRD) ISSN: 2456-6470

\begin{tabular}{|l|l|}
\hline \multicolumn{1}{|c|}{ Specimen } & \multicolumn{2}{|c|}{ Moisture Content (\%) } \\
\hline Loligo duvauceli (d'Orbigny, 1848) & 83.35 \\
\hline Octopus macropus (Risso, 1826) & 82.57 \\
\hline Sepia aculeata (Ferussac and d'Orbigny, 1848 ) & 84.44 \\
\hline Sepiella inermis (Ferussac and d'Orbigny, 1848 ) & 81.19 \\
\hline
\end{tabular}

Table - 12: Nutritive value (Moisture Content) of marine edible cephalopods available at Digha coast (Analysis result - CIFT)

The carbohydrate values fluctuate widely in all the months. Maximum value is in July and minimum in May. In general glycogen content shows variations with the breeding behaviour and development of the gonad. Carbohydrate percentage is at the peak in July and it decreases in September. In the month of November, the glycogen value is high again and the lowest value is recorded during the pre monsoon season. Glycogen has been long considered to be the principle reserve of marine bivalves ${ }^{9-13}$. The result after analysis of carbohydrate content in dry condition of 4 edible cephalopods is shown in table number -13

\begin{tabular}{|l|l|}
\hline \multicolumn{1}{|c|}{ Specimen } & \multicolumn{1}{c|}{ Carbohydrate Content (\%) } \\
\hline Loligo duvauceli (d'Orbigny, 1848) & 2.14 \\
\hline Octopus macropus (Risso, 1826) & 1.74 \\
\hline Sepia aculeata (Ferussac and d'Orbigny, 1848 ) & 1.76 \\
\hline Sepiella inermis (Ferussac and d'Orbigny, 1848 ) & 1.32 \\
\hline
\end{tabular}

Table - 13: Nutritive value (Carbohydrate Content) of marine edible bivalves available at Digha coast (Analysis result - CIFT)

The protein content of molluscan species is at relatively high level trough out the year. It is being maximum in the month of May and minimum in the month of November. In the month of March and April, the protein content is high reaching its peak in the month of May. Afterwards, it decreases during the monsoon period. Generally seasonal changes in the biochemical composition are the characteristics of the seasonal activities of bivalves. Variations in biochemical constituents seem to be mainly influenced by reproductive cycle and availability of food. In marine molluscs, the reproductive cycle is governed by a number of factors like salinity, water temperature, day length and density of the surrounding medium ${ }^{\mathbf{9}-13}$. The result after analysis of protein content in dry condition of 4 edible cephalopods is shown in table number -14

\begin{tabular}{|l|l|}
\hline \multicolumn{1}{|c|}{ Specimen } & \multicolumn{1}{c|}{ Protein Content (\%) } \\
\hline Loligo duvauceli (d'Orbigny, 1848) & 12.17 \\
\hline Octopus macropus (Risso, 1826) & 12.71 \\
\hline Sepia aculeata (Ferussac and d'Orbigny, 1848) & 11.48 \\
\hline Sepiella inermis (Ferussac and d'Orbigny, 1848 ) & 14.53 \\
\hline
\end{tabular}

Table - 14: Nutritive value (Protein Content) of marine edible cephalopods available at Digha coast

The lipid content of marine molluscs shows a gradual increase from the month of February and peak in the gravid population of May before spawning. In June, the lipid content is sharply decreased and remained at low level up to July due to continuous spawning. Possibility of an increase in lipid content in bivalves during phytoplankton bloom has been reported. Lipid levels of almost same magnitude have been reported in the literatures from Indian waters ${ }^{\mathbf{9 - 1 3}}$. The result after analysis of crude fat content in dry condition of 4 edible cephalopods is shown in table number -15 
International Journal of Trend in Scientific Research and Development (IJTSRD) ISSN: 2456-6470

\begin{tabular}{|l|l|}
\hline \multicolumn{1}{|c|}{ Specimen } & \multicolumn{2}{|c|}{ Crude Fat Content (\%) } \\
\hline Loligo duvauceli (d'Orbigny, 1848) & 0.56 \\
\hline Octopus macropus (Risso, 1826) & 0.60 \\
\hline Sepia aculeata (Ferussac and d'Orbigny, 1848 ) & 0.51 \\
\hline Sepiella inermis (Ferussac and d'Orbigny, 1848 ) & 0.69 \\
\hline
\end{tabular}

\section{Table - 15: Nutritive value (Fat Content) of marine edible cephalopods available at Digha coast}

The ash content in marine molluscs body also fluctuates in a year. It is highest in the month of May and lowest in the month of August. Ash content is similar with percentage of protein and lipid. However, changes in carbohydrate percentage show a completely different resulting in an inverse relationship between carbohydrate and protein ${ }^{9-13}$. The result after analysis of ash content in dry condition of 4 edible cephalopods is shown in table number -16

\begin{tabular}{|l|l|}
\hline Specimen & Ash Content (\%) \\
\hline Loligo duvauceli (d'Orbigny, 1848) & 0.76 \\
\hline Octopus macropus (Risso, 1826) & 1.41 \\
\hline Sepia aculeata (Ferussac and d'Orbigny, 1848 ) & 0.90 \\
\hline Sepiella inermis (Ferussac and d'Orbigny, 1848 ) & 1.34 \\
\hline
\end{tabular}

Table - 16: Nutritive value (Ash Content) of marine edible cephalopods available at Digha coast (Analysis result - CIFT)

The minerals are also a needful nutrient in food items required to save human body from some specific diseases. Depending upon the requirement, minerals are two types i.e. macro or major elements and micro or minor elements. The macro or major elements are required in small quantities but most essential for animal and plant nutrition. The macro or major elements are $\mathrm{C}, \mathrm{H}, \mathrm{O}, \mathrm{N}, \mathrm{S}, \mathrm{P}, \mathrm{K}, \mathrm{Ca}, \mathrm{Mg}$ and $\mathrm{Fe}$. The micro or minor element is otherwise known as trace element. The micro or minor elements are required in human body in very small quantities as food nutrients. The micro or minor elements are $\mathrm{B}, \mathrm{Mo}, \mathrm{Si}, \mathrm{Cu}, \mathrm{Mn}, \mathrm{Na}$, and $\mathrm{Zn}{ }^{9-13}$. The result after analysis of minerals content $(\mathrm{Na}, \mathrm{K}$ and $\mathrm{Ca})$ in dry condition of 4 edible cephalopods is shown in table number -17

\begin{tabular}{|l|l|l|}
\hline \multirow{2}{*}{ Loligo duvauceli (d'Orbigny, 1848) } & \multicolumn{2}{|c|}{ Minerals Content } \\
\hline \multirow{4}{*}{ Octopus macropus (Risso, 1826) } & $\mathrm{Na}$ & $994.03 \mathrm{mg} / 100 \mathrm{~g}$ \\
\hline & $\mathrm{K}$ & $1391.65 \mathrm{mg} / 100 \mathrm{~g}$ \\
\hline & $\mathrm{Ca}$ & $198.80 \mathrm{mg} / 100 \mathrm{~g}$ \\
\hline \multirow{3}{*}{ Sepia aculeata (Ferussac and d'Orbigny, 1848 ) } & $\mathrm{Na}$ & $2081.26 \mathrm{mg} / 100 \mathrm{~g}$ \\
\hline & $\mathrm{K}$ & $1688.00 \mathrm{mg} / 100 \mathrm{~g}$ \\
\hline & $\mathrm{Ca}$ & $401.10 \mathrm{mg} / 100 \mathrm{~g}$ \\
\hline \multirow{3}{*}{ Sepiella inermis (Ferussac and d'Orbigny, 1848 ) } & $\mathrm{K}$ & $1603.20 \mathrm{mg} / 100 \mathrm{~g}$ \\
\hline & $\mathrm{Ca}$ & $1503.00 \mathrm{mg} / 100 \mathrm{~g}$ \\
\hline & $\mathrm{Na}$ & $340.60 \mathrm{mg} / 100 \mathrm{~g}$ \\
\hline & $\mathrm{K}$ & $1569.03 \mathrm{mg} / 100 \mathrm{~g}$ \\
\hline & $\mathrm{Ca}$ & $1882.84 \mathrm{mg} / 100 \mathrm{~g}$ \\
\hline
\end{tabular}

Table - 17: Nutritive value (Minerals content) of marine edible cephalopods available at Digha coast (Analysis result - CIFT)

The population studies of molluscs (benthic invertebrates) show that the high species diversity at Udaypur provides suitable substratum for molluscan population. The habitats in these localities comprise of estuary with continuous flow of fresh water and regular tidal rhythm of inflow and out flow of water. 
None of the molluscs species shows abundant distribution in Mohana because of increasing fishing activities in the area. Old Digha with low species diversity shows many molluscan species in sparse distribution which may be due to increasing anthropogenic activity day after day in the area. Old Digha shows till now very little molluscan species with moderate distribution which was due to construction of wall and cement boulder around coast provided suitable substratum of the settlement of bivalves in recent time. The relationship between energy budgets, habitat structure, physiological parameters and population diversity has been investigated most extensively in marine bivalves.

Difference between populations at different locations may represent the response to different levels of stress. The differences in the densities can be accounted to the greater number of younger individuals settled and grown. Such differences of the reproductive success are common in species that use an indirect mode of reproduction and several biotic and abiotic factors can be responsible.

It is suggested that the temperature was principal factor controlling the onset of shell growth. Further, in the view of density and size distribution of the marine bivalves, the differences in the start of the growing season observed between younger and older generations can probably be related to the presence or absence of reproductive activity and to energy allocation. The differences in the population densities at different locations under the present study can also probably be related to the presence or absence of reproductive activity and to energy allocation. However, uncoupled growth patterns of shell and soft tissue seem to be a general phenomenon in marine bivalve populations.

The available marine molluscan species found at Digha coast are not all suitable for human consumption because peculiar smell, toxic and harmful poisonous effect of molluscs flesh on human body. Only 12 species out of 54 numbers of bivalves, 2 species out of 35 numbers of gastropods and 4 species out of 4 numbers of cephalopods are edible. The meat of edible molluscs available at Digha coast is not properly utilized as human food. Local people do not consume them except Cephalopods because they are all getting different varieties of marine fishes in low price value. But in future the molluscan meat may be eaten by local poor people due to containing high protein in comparison with marine fishes and also scarcity of marine fishes. A little number of very poor common people takes cephalopods meat as their daily food at Digha and surrounding areas.

A huge amount of eroded sediments, fly ash along with several other industrial discharges mixed with the water of Bay of Bengal and have made every year this coast unsuitable for living fishes, prawns, shrimps, molluscs and other biodiversity which are economically important or not but play important role in existence of human life directly or indirectly. The water pollution is directly reflected by the steady decline of the abundance of finfish and shellfish seeds, smaller fin fishes and other nektonic forms. The data collected during last 10 years from the Department of Fishery, Government of West Bengal, relating to fish and shellfish landings at Digha and surrounding coast, reveals a rapid reduction of total landings of different fishery resources ${ }^{14}$.

Operation of huge number of fishing trawlers with nylon thread gears may be considered a major factor for such down going condition. It is well known that oil and other related organic products after being discharged from different fishing trawlers, ships and other marine vessels pollute considerably both pelagic and benthic environment. Domestic sewage in small quantities is known to fertile the sea water which leads to an increase in marine productivity because of eutrophication. Waste disposal from the tourist centers of Digha and nearby fishing harbours of Sankarpur contributes pollutants into the nearby estuaries and small marshes. We should be sincere immediately to protect the biodiversity of Digha coast in West Bengal. It is hopeful that government has taken some primary initiatives to save Digha. Beach side is concreted and very clean. There is restricted and carefully watched any untoward incident that hamper the natural and social environment of Digha ${ }^{14}$.

At Digha it is seen that all ghats (spots) do not show the availability of all marine molluscs population because increasing tourism, pollution, fluctuation of water parameters throughout the year and other anthropogenic activities. It proves that marine molluscan fauna are under heavy pressure. Present study shows that Udaypur ghat (spot) and Hospital ghat (spot) is most suitable location of marine molluscs population. However Digha Mohana and other ghats (spots) are under pressure due to early mentioned causes. Maximum marine molluscan 
species are available at Digha coast during winter season in the month from October to February. On the other hand molluscan population is minimum during rainy season in the month from June to August in a year. Public (tourist) should be conscious about biodiversity of all ecosystems. All of them should know how different varieties of marine molluses species as well as other populations are beneficial and play role in existence of human life. The law CRZ (Coastal Regulation Zone) must be implemented strictly by Government both State and Central for survival of marine population.

It is also observed that, molluscan species are also being increasingly threatened at Digha coast due to uncontrolled collection of live specimen by local women for some ornamental purposes and for zoological excursions. Very often they continued their works while collecting a large number of specimens. Simultaneously, they also collected a number of species which are now rare due to destruction of their habitat and over exploitation.

In view of faunal richness which is now threatened by exploitation of marine fishery resources, tourism without eco friendly awareness and overall socioeconomic development, this coastal zone demands more protective measures.

Based on our studies, we have some humble recommendations for conservation of marine molluscs like an awareness program for the fishermen, tourists, collectors of zoological samples has to be undertaken, as the fishermen and also the over-enthusiastic tourists destroy the living molluscs and other marine aquatic organisms (with or without their knowledge) Restrictions period (May and June) may be imposed on fishing activities except permissible seasons, and also on the mesh size regulation $(>90 \mathrm{~mm})$ of fishing nets.

Drag net operation on intertidal areas is to be banned or restricted and selective sorting and releasing of by catch organisms in the sea before their death should be made compulsory.

General tourists as well as excursion team often collect a lot of specimen in the first flush of enthusiasm but it is observed that most of those are finally dumped on the beach where the animals are allowed to die and rot. This habit has also to be banned immediately.
Over exploitation by repeatedly collecting the same organisms (especially the various species of live bivalve, gastropods, cephalopods and others) year after year from beach by the study team from various educational institutions for display in their museum should be restricted.

In this context an alternative way might be taken as taking a number of photographs of the organisms from various angles without disturbing them and to collect only very few examples of each species, particularly of rare and poorly populated species. Comprehensive assessment (chemical, biological and environmental) of by catch organisms in the light of fishery exploitation and bio-medical studies may be invited.

\section{CONCLUSION}

During the study period from August - 2012 to July 2017, we had an interview with some poor villagers and fishermen lived in coastal villages at Digha. From this survey it is known that 12 bivalves species belonging to 5 orders, 6 families and 8 genera out of 54 available bivalves species, 2 gastropods species belonging to 2 orders, 2 families and 2 genera out of 35 available gastropods species and 4 cephalopods species belonging to 3 orders, 3 families and 4 genera out of 4 available cephalopods species are edible. Digha is now under heavy pressure due to gathering of tourists in huge number. The molluscan species diversity is now going down year after year owing to water pollution, over exploitation by repeatedly collecting the same organisms, anthropogenic activities, over fishing. Shrimp seed collection and confirm death of other organism's seed etc. We collected 54 bivalves 35 gastropods and 4 cephalopods for first 2 years study period but this number will go down in future if awareness programs are not started immediately among the fishermen, villagers, tourists, students etc. Government has taken some immediate action to protect biodiversity at Digha coast but it is not sufficient and will not be prolific until local people change themselves to acquire knowledge.

\section{ACKNOWLEDGEMENT}

Authors are thankful to respected teacher Dr. Bidhan Chandra Patra, Coordinator, Department of Aquaculture Management and Technology and Associate Professor, Department of Zoology, 
Vidyasagar University, Dr. Anil Mahapatra, Officer in - Charge and Sri Prasad Chandra Tudu, Assistant Zoologist, Digha Marine Aquarium and Regional Centre, Zoological Survey of India, Digha : Purba Medinipur : West Bengal, Dr. G. Rajeswari, Principal Scientist and Officer - in - Charge, Dr. Vi-Ji. P. (Scientist), Dr. Jesmi Deb Barma (Scientist) and Dr. Dhiju Das (Laboratory Technologist), Central Institute of Fisheries Technology (CIFT), Visakhapatnam Research Centre, Vizag, Andhra Pradesh, India for extending their helping hands in various ways during this study.

\section{REFERENCES}

1) Winckworth R. (1940). New species of shells from Madras. Journal of Molluscan Studies 24(2), 41-43.

2) Subba Rao N.V., Dey A. and Barua S. (1992). Estuarine \& marine molluscs. Fauna of West Bengal, State Fauna Series, 3, Part-9: 129-268. Zool. Survey of India.

3) Cameron R. (2016). Slugs and snails. Harper Collins Publishers, London, 508 pp.

ISBN 978-0-00 - 7113019

4) Strong E. E., Gargominy O., Ponder W. F. \& Bouchet P. (2008). Global Diversity of Gastropods (Gastropoda; Mollusca) in Freshwater. Hydrobiologia 595: 149-166. hdl. handle.net doi: 10.1007/s10750- 007-9012-6.

5) Yennawar Prasanna and Tudu Prasad (2014). Study of Macro benthic (Invertebrate) Fauna Around Digha Coast. Marine Aquarium and Regional Centre, ZSI, Digha - 721428, WB. Rec. Zool. Surv, 114 (Part- 2),

341-351.

6) Subba Rao N.V., Dey A. and Barua S. (1995). Molluscs of Hugly Matla Estuarine Ecosystems Series, 2:41-91. Zool. Surv. India.

7) Ramakrishna S.C. and Dey M.A. (2010). Annotated Check list of Indian Marine Molluscs. Rec. Zool. Surv.India, Oce. Paper No. 320.

8) Nair D.V. and Rao K.S. (1997). The Commercial Molluscs of India. Edited by CMFRI, Cochin, India.

9) Kumari L.K. and Nair V. R. (1989). Seasonal Variation in the Proximate Composition of Rock Oyster Saccostrea cucullata from Bombay Coast. J. India Fish. Asso.,19, 19-24.

10) Sing Yambem Tenjing, Krishnamoorthy Machina andTrippeswamySeetharamaiah, (2012). Seasonal
Changes in the Biochemical Composition of Wedge Clam, Donax scortum from the Padukere Beach, Karnataka. Department of Post- graduate Studies and Research in Biosciences, Mangalore University, Mangalagangothri -574199, Karnataka, India. Recent Research in Science and Technology. 4(12), 12-17. 12.

11) Nagabhushanan R. and Talikhedkar P.M. (1977). Seasonal variations in protein, fat and glycogen of the Wedge clam Donax cuneatus. Indian J. Mar.Sci., 6, 85-87.

12) Giese A.C. (1969). A new approach to the biochemical composition of the mollusks body. Ocanogr. Mar. Biol. Ann.Rev.7, 175-229.

13) Fatima M. (1996). Growth Indices, Nutritive Value and Chemical Significance of the Green Mussel, Ph-D Thesis, University of Karachi, Karachi

14) Chakraborty S.K. (2010). Coastal Environment of Midnapore, West Bengal: Potential Threats and Management, India. Journal of Coastal Environment, 1(1), 27-40 